\title{
End of life issues in brain tumor patients
}

\author{
Andrea Pace - Cherubino Di Lorenzo · \\ Lara Guariglia · Bruno Jandolo • \\ Carmine M. Carapella $\cdot$ Alfredo Pompili
}

Published online: 25 October 2008

(C) Springer Science+Business Media, LLC. 2008

\section{Erratum to: J Neurooncol}

\section{DOI 10.1007/s11060-008-9670-x}

The second author's family name was misrepresented in the original publication.

The online version of the original article can be found under doi: 10.1007/s11060-008-9670-x.

\footnotetext{
A. Pace $(\bowtie) \cdot$ C. Di Lorenzo · L. Guariglia · B. Jandolo · C. M. Carapella - A. Pompili

Department of Neuroscience, Palliative Home-Care Unit for Brain Tumor Patients, Regina Elena National Cancer Institute, via Chianesi 53, Rome 00144, Italy

e-mail: pace@ifo.it

C. Di Lorenzo

UCADH, University of Rome "La Sapienza",

Polo Pontino-ICOT, Latina, Italy
} 